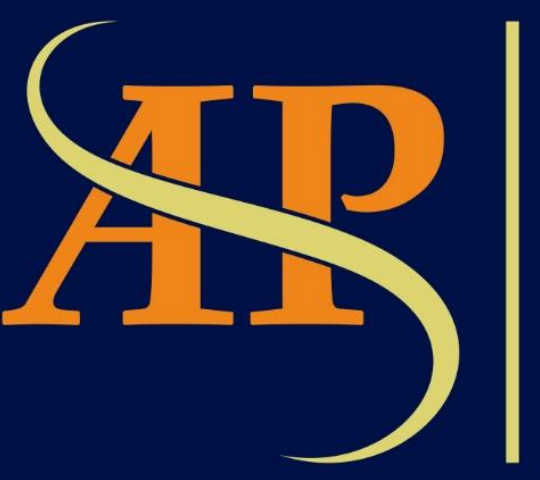

JURNAL

ASIA

PACIFIC

STUDIES

Journal of International Relations Study Program

Faculty of Social and Political Sciences

Universitas Kristen Indonesia

Volume I | Number 2 | July - December 2017 


\title{
PROYEKSI INDONESIA BERGABUNG DALAM TRANS-PACIFIC PARTNERSHIP
}

\author{
Arthuur Jeverson Maya \\ Ilmu Hubungan Internasional, Fakultas Ilmu Sosial dan Ilmu Politik, Universitas Kristen Indonesia, Jl. Mayjen \\ Sutoyo no.2, Cawang - Jakarta, 13630, Indonesia \\ arthuurjeversonmaya@yahoo.com
}

\begin{abstract}
This article discusses the projection high standard free trade cooperation of the Trans-Pacific Partnership (TPP) which attracts Indonesia to join under President Joko Widodo (Jokowi). It is analyzed predictively calculation of the situation that occurred if Indonesia was determined to join TPP in the future. This is analyzed using the concept of political communication, the concept of neoliberalism, and the critical theory of neomarxism, supported by qualitative research methods and data collection from secondary sources. Found evidence indicating the inability of Indonesia's competitiveness against majority member states of TPP. As a result, they have the potential to engage in exploitative, dependent, and monopoly relationships with Indonesia's economic and social if join TPP at this time. Therefore, it is recommended to reject TPP until Indonesia has the optimal competitiveness ability to refer to the effectiveness, efficiency, and productivity of the population, low poverty, high gross national income percapita, high value human development index, high value global competitive advantage, anti-corruption business bureaucracy, and adequate infrastructure.
\end{abstract}

Keywords: Trans-Pacific Partnership (TPP), Indonesia, Neoliberalism, Neomarxism

\begin{abstract}
Abstrak
Artikel ini membahas proyeksi kerja sama perdagangan bebas berstandar tinggi Trans-Pacific Partnership (TPP) yang menarik minat Indonesia dibawah kepemimpinan Presiden Joko Widodo (Jokowi) untuk bergabung di dalamnya. Ia dianalisis prediktif mengenai kalkulasi situasi yang terjadi apabila Indonesia nekat bergabung dalam TPP di masa depan. Ini dianalisa menggunakan konsep komunikasi politik, konsep neo-liberalisme, dan teori kritis neo-marxisme, didukung metode penelitian kualitatif dan pengumpulan data dari sumber sekunder. Ditemukan bukti-bukti yang mengindikasikan ketidakmampuan Indonesia bersaing dengan mayoritas negara-negara anggota TPP. Akibatnya, mereka berpotensi melakukan hubungan eksploitatif, ketergantungan, dan monopoli ekonomi dan sosial indonesia jika memutuskan bergabung dalam TPP saat ini. Oleh sebab itu, direkomendasikan untuk menolak TPP sampai Indonesia memiliki kemampuan daya saing optimal mengacu efektivitas, efisiensi, dan produktifitas populasi, kemiskinan rendah, pendapatan nasional perkapita tinggi, indeks pembangunan manusia tinggi, keunggulan nilai dalam menghadapi persaingan global, birokrasi bisnis anti-korupsi, dan infrastruktur yang memadai.
\end{abstract}

Kata Kunci: Trans-Pacific Partnership (TPP), Indonesia, Neoliberalisme, Neomarxisme 


\section{Pendahuluan}

\subsection{Latar Belakang}

Pada era globalisasi saat ini, falsafah neoliberalisme yang menyuarakan prinsip kapitalisme telah menjadi acuan dunia. Ia ditandai eksistensi 22 tahun World Trade Organization (WTO) beranggotakan 164 negara, kemunculan berbagai perjanjian perdagangan bebas bilateral dan multilateral di antaranya Mercosur, Japan-Indonesia Economic Partnership Agreement, ASEAN Free Trade Area (AFTA), ASEAN-China Free Trade Area (ACFTA), South Asian Free Trade Area (SAFTA), Pacific Agreement on Closer Economic Relations (PACER), G-3 Free Trade Agreement (G-3), Greater Arab Free Trade Area (GAFTA), Dominican Republic-Central America Free Trade Agreement (DR-CAFTA), East African Community (EAC), Grains Trade Convention (GTC), Food Aid Convention (FAC), North American Free Trade Agreement (NAFTA), Pacific Alliance Free Trade Area (PAFTA), Southern African Development Community Free Trade Area (SADCFTA), Trans-Pacific Partnership (TPP), dan lain sebagainya, serta merebaknya korporasi-korporasi multinasional (Multinational Corporation, MNC) 'raksasa' seperti Ford, Petronas, Honda, Samsung, Sony, Chevron, Coca-Cola, Axis Bank Ltd, Acer Inc, Gazprom, General Electric, Goodyear Tire and Rubber Company Google, Haier, Halliburton, Microsoft, Motorola, Nestlé, dan seterusnya. Ini merefleksikan integrasi, interkoneksi, dan interdepedensi jaringan ekonomi, perdagangan, pasar, dan masyarakat antarnegara tanpa dihalangi batas-batas kedaulatan tradisional. (Aggarwal dan Lee 2010, 2-8).

Efeknya beragam persaingan ekonomi, perdagangan, dan pasar semakin kompetitif, sistem produksi mengalami kemajuan dan inovasi terus menerus, standar hidup masyarakat meningkat seiring kemudahan aksesibilitas, transportasi, teknologi, komunikasi, informasi, dan lainnya, di sisi lain terjadi ketidakseimbangan dan kesenjangan distribusi ekonomi, sosial, dan kesejahteraan yang menciptakan lingkaran sistem eksploitasi antara negara maju terhadap negara berkembang, juga kemunculan dominasi segelintir masyarakat kaya yang ditopang mayoritas masyarakat miskin. Sebagai contoh dari 189 negara di dunia hanya terdapat 78 negara berkategori maju dengan pendapatan perkapita di atas $\$ 12.475$, sisanya berkembang, sedang berkembang, dan terbelakang; MNC asal Amerika Serikat (AS), Inggris, Belanda berjulukan 'The Seven Sisters' (Shell, British Petroleum (BP), Exxon, Chevron, Mobil, Texaco, dan Gulf Oil) menguasai $85 \%$ cadangan minyak dunia, hanya $1 \%$ dikuasai Badan Usaha Milik Negara (BUMN) (Kasali 2016); PT. Freeport asal AS telah 50 tahun menambang emas di Mimika, Papua, Indonesia, namun kemiskinan di sana menempati urutan pertama penduduk termiskin se-Indonesia (Detik 2015); dan seluruh kekayaan Indonesia hanya dikuasai 20\% dari total 262 juta penduduknya (Julianto 2016).

Salah satu agenda neoliberalisme yang mengemuka adalah perjanjian TPP. Ia ditandatangani di Auckland, Selandia Baru, tanggal 4 Februari 2016 oleh Australia, Brunei Darusalam, Kanada, Chile, Jepang, Malaysia, Meksiko, Selandia Baru, Peru, Singapura, Vietnam, dan (AS keluar tanggal tanggal 23 Januari 2017) (Lee dan Itakura 2017, 8-12). Ini bertujuan untuk memfasilitasi dan mendorong ekspansi perdagangan barang dan jasa dalam persaingan sehat tanpa hambatan antarnegara anggota TPP (member states, MS); meningkatkan peluang investasi dan perlindungan yang memadai dan efektif atas hak kekayaan intelektual (HAKI) mereka; dan penciptaan mekanisme pencegahan dan penyelesaian sengketa yang terjadi di antara mereka. Hal tersebut ditempuh melalui komitmen mereka atas isi perjanjian tentang $30 \mathrm{BAB}$ fitur-fitur kesepakatan perdagangan yang menuju pendekatan komitmen integrasi ekonomi MS terkait perdagangan yang inklusif, akses pasar yang komprehensif, dan pengentasan ragam tantangan perdagangan baru (New Zealand Ministry of Foreign Affairs 2016, 1-30). 
TPP membawa daya tarik tersendiri bagi negara-negara trans-pacific lainnya, seperti Kolombia, Filipina, Thailand, Cina, Korea Selatan, Taiwan, Laos, Kamboja, Bangladesh, termasuk Indonesia dibawah kepemimpinan Presiden Jokowi ketika bertemu Obama di Washinton DC, AS, bulan Oktober 2015 (CNN Indonesia 2016). Dari ketertarikan tersebut sampai saat ini, pemerintah Indonesia belum mengambil kebijakan bergabung atau tidak karena masih tahap pembelajaran dan pengkajian mendalam untuk melihat besaran untung atau ruginya. Untuk itu, penulis mengulas, menganalisis, dan memprediksikan secara ilmiah proyeksi Indonesia ketika bergabung dalam TPP berlandaskan perspektif kritik neo-marxisme terhadap neo-liberalisme.

\subsection{Rumusan Masalah}

Berdasarkan uraian latar belakang di atas maka dirumuskan permasalahan bagaimana proyeksi Indonesia untuk bergabung dalam TPP?

\subsection{Maksud dan Tujuan}

Penelitian ini bermaksud mengeksplorasi dan menganalisis perjanjian TPP yang mendorong ketertarikan Indonesia dibawah kepemimpinan Jokowi dengan membawa tujuan untuk mengetahui proyeksi (memperkirakan keadaan) secara ilmiah apabila Indonesia bergabung dalam TPP di masa mendatang menggunakan data saat ini.

\subsection{Kegunaan Penelitian}

Penelitian ini diharapkan mampu menjadi rujukan dan rekomendasi bagi akademisi, praktisi, dan pemerintah Indonesia dalam mengkomunikasikan, mengkalkulasikan, memformulasikan, dan mengambil kebijakan untuk bergabung atau tidak dalam TPP.

\section{Kajian pustaka}

\subsection{Komunikasi Politik dan Neoliberalisme}

Melihat ketertarikan Indonesia dibawah kepemimpinan Jokowi untuk bergabung dalam keanggotaan perjanjian TPP disampaikan dalam bentuk komunikasi politik. Ia dipahami Gabriel Almond sebagai semua fungsi yang dilakukan dalam sistem politik, sosialisasi politik, artikulasi minat, agregasi kepentingan, pembuatan peraturan, penerapan peraturan, dan keputusan undang-undang melalui proses komunikasi (Almond 1956, 395-396). Ini berjalan dalam proses penyampaian pesan-pesan politik secara langsung maupun tidak langsung dalam sidang, rapat, konvensi, konferensi pers, demonstrasi, media televisi, lokakarya, hotline, dan lain sebagainya berorientasi keinginan, minat, dan nilai pencapaian tujuan dalam kekuasaan, pemerintahan, dan pengambilan kebijakan pemerintah oleh para aktor politik yang dianggap relevan, seperti presiden, menteri, legislatif, yudikatif, praktisi, akademisi, maupun masyarakat sipil (Arifin 2003, 72-84).

TPP sendiri mengambil dasar filosofis Neo-liberalisme yang semakin populer saat ini. Ia bersumber dari tradisi liberalisme sebagai filsafat kehidupan yang mengagungkan kebebasan setiap individu manusia dalam kesempatan dan kesetaraan berfikir, berusaha, dan bersaing satu sama lain untuk memenuhi kepentingannya di bawah panji-panji hukum abadi yang adil dengan menolak adanya pembatasan-pembatasan eksternal. Oleh sebab itu, John Locke, Jacques Rousseau, Alexis de Tocqueville, John Rawls, Ronald Dworkin, dan Robert Nozick mempercayai negara sebatas alat yang tunduk menurut kehendak rakyat untuk menjamin 
kebebasan individu sebagai "hak privat". Ini merasuk sendi kehidupan politik dan ekonomi "liberalisme klasik" yang dikembangkan Adam Smith dan David Ricardo memandang pentingnya peran "pasif" negara terkait urusan pasar untuk mencapai kesejahteraan masyarakat.

Liberalisme klasik menguasai Eropa selama 1,5 abad melahirkan kesenjangan sosial, kemiskinan, dan pengangguran yang parah di Inggris, Jerman, Perancis, AS, dan berpuncak peristiwa "depresi besar dunia" tahun 1929. Mengadopsi pemikiran John Stuart Mill, John Maynard Keynes tampil mengoreksinya dan memberikan varian "liberalisme sosial" mengenai perlunya peran "aktif" negara dalam menjaga stabilitas pasar, sambil mendukung dan mendistribusikan nilai-nilai sosial yang adil terhadap masyarakat. Ia membuat intervensi negara terlalu besar berakibat inefisiensi, krisis, dan stagflasi ekonomi dunia tahun 1970-an hingga meruntuhkan sistem Bretton Woods. Ini melahirkan pemikiran Friedrich von Hayek dan Milton Friedman menyuarakan kembali kebangkitan liberalisme klasik radikal menentang liberalisme sosial dibungkus istilah "neo-liberalisme".

Neo-liberalisme memandang negara bentuk keterbelakangan, penyebab konflik, dan tidak ekonomis, sementara pasar bernilai kompetisi, kerja sama, kemajuan, kemapanan, dan kesejahteraan. Negara hanya dibutuhkan untuk urusan-urusan bersifat kemaslahatan bersama yang terkontrol, seperti jaminan keamanan, penegakan hukum, pembuatan regulasi, dan lainnya, tetapi harus benar-benar "diminimalisir" sampai "dipisahkan" dengan urusan pasar menjadi hak privat. Ia menyuburkan kapitalisme ketika ekonomi, pasar, perdagangan, industri dan alat-alat produksi dikendalikan oleh individu (swasta) secara tidak terkontrol untuk meraih keuntungan sebesar-besarnya. Ini menunjukan empat ciri utama neoliberalisme yaitu: (1) pengakuan hak-hak individu masyarakat yang setara, otonom, dan bebas dalam berkompetisi dan berinovasi untuk meraih kemakmuran; (2) struktur ekonomi kapitalis yang bertujuan memperoleh keuntungan sebesar-besarnya; (3) superioritas pasar; dan (4) pembatasan dan minimalisir peran negara dalam pasar (Burchill dan Linklater 2015, 41-83). Keempatnya menjadi jalan menuju kemajuan, kemakmuran, dan kesejahteraan masyarakat, "tidak ada alternatif lain" kata mantan Perdana Menteri Inggris Margaret Thatcher, apalagi Uni Soviet sudah runtuh (Sumner 2016).

Uraian konsep komunikasi politik di atas dijadikan landasan penulis untuk mengargumentasikan ketertarikan Indonesia terhadap TPP melalui adanya serangkaian pesanpesan komunikasi yang menyiratkan kesan, minat, dan tingkah laku untuk bergabung dalam TPP dari aktor-aktor dalam perpolitikan Indonesia yang relevan. Sementara konsep neoliberalisme dalam variabel-variabel pengakuan hak-hak individu masyarakat untuk meraih kemakmuran sebesar-besarnya, struktur ekonomi kapitalis, superioritas pasar, dan minimalisir peran negara dalam pasar menjadi acuan yang mengkarakteristikkan isi pesan perjanjian TPP.

\subsection{Kritik Neomarxisme terhadap Neoliberalisme}

Karl Marx memperingatkan bahwa neoliberalisme yang mengagungkan sistem ekonomi kapitalis adalah 'parasit' penyebar 'penyakit' ketidakadilan sosial. Ia menciptakan ketidakmerataan hubungan tanpa aturan antarkelas pemilik modal-produksi (borjuis) yang mencari keuntungan sebesar-besarnya melalui eksploitasi kelas pekerja-buruh (proletariat) menggunakan upah minimal. Didukung Bill Warren, Joan Robinson, Paul Baran, Paul Sweezy, Gunder Frank, dan Immanuel Wallerstein menyuarakan pembaharuan kritis Marxisme dalam pemikiran "neo-marxisme" mengenai korelasi sejarah dan kapitalis sebagai masalah sosial menekankan konflik kelas dalam aktivitas negara dari perspektif holistik dan dialektis. Mereka menawarkan ide mengenai sistem internasional yang penuh agenda neoliberalisme membentuk hubungan struktur kelas kapitalistik layaknya borjuis dan proletariat.

Kategori kelas borjuis berisi aktor negara maju, dan modern (dominan atau core) memiliki sumber dana, alat, daya saing, teknologi produksi tinggi dan masif, sementara kelas 
proletariat dari negara berkembang dan/atau sedang berkembang (non-dominan atau pheriphery) bermodalkan dana, alat, dan teknologi minim, namun kaya sumber daya alam dan manusia. Hubungan antara negara dominan dengan negara non-dominan selalu bersifat "dependensia" yang mencerminkan kekuasaan eksploratif "kapitalisme dua-kutub," ketika negara dominan menggunakan segala alat dan usaha yang tampak dibenarkan seperti pasar bebas, penghapusan hambatan perdagangan, investasi, HAKI, dan seterusnya menyimpan agenda tersembunyi dalam upaya membangun, mengekang, mengeksploitasi, dan mempertahankan ketergantungan negara pheriphery agar selalu terbelakang demi meraih keuntungan sebesar-besarnya (Burchill dan Linklater 2015, 176-229). Ini dijadikan landasan penulis dalam mengeksplorasi dan menganalisis proyeksi Indonesia ketika bergabung dalam TPP bergantung pada statusnya yang berkategori dominan atau non-dominan dibandingkan MS.

Penentuan kategori Indonesia tersebut menggunakan indikator-indikator jumlah populasi penduduk berkombinasi dengan tingkat kemiskinan masyarakat, pendapatan nasional (gross national income, GNI) perkapita masyarakat, indeks pembangunan manusia (human development index, HDI), dan kemampuan daya saing global (global competitive advantage, GCA) (Betzelt et al. 2014, 2-9). Apabila populasi penduduk Indonesia yang ada memiliki tingkat kemiskinan rendah, GNI tinggi, HDI tinggi, dan GCA tinggi dibandingkan sebagian besar MS maka berstatus dominan sehingga TPP cenderung menguntungkan untuk diikuti. Sementara, jika populasi penduduknya diwarnai kemiskinan yang tinggi, GNI rendah, HDI rendah, dan GCA rendah dibandingkan sebagian besar MS maka berstatus non-dominan sehingga TPP cenderung merugikan ketika diikuti karena menjebaknya dalam ketergantungan dan ekspolitasi dari MS dominan.

Seluruh uraian konsep komunikasi politik, konsep neoliberalisme, dan teori neomarxisme dijadikan pengembangan masalah dan kerangka pemikiran penulis untuk menjelaskan dan menjawab persoalan proyeksi Indonesia bergabung dalam TPP sebagaimana Bagan 1 berikut:

\section{Bagan 1. Alur Pemikiran}

\section{Ketertarikan Indonesia bergabung dalam TPP}

1. Pesan-pesan politik dari aktor politik Indonesia yang relevan menyiratkan kesan, minat, dan tingkah laku untuk bergabung dalam TPP.

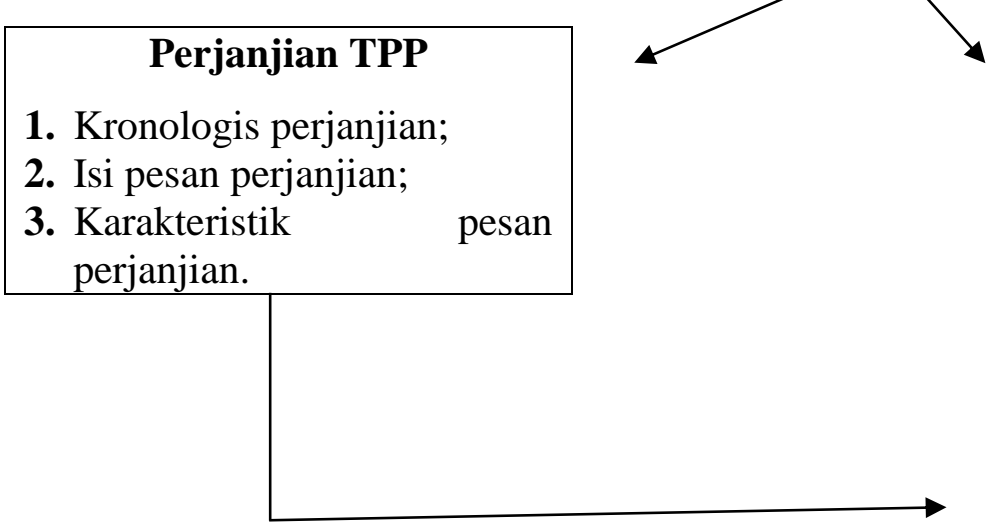

\section{Proyeksi Indonesia bergabung dalam TPP}

1. Jumlah populasi penduduk;

2. Tingkat kemiskinan;

3. GNI;

4. HDI;

5. GCA;

6. Kategori status Indonesia dibandingkan MS dominan atau non-dominan.

\section{Objek dan Metode Penelitian}




\subsection{Metode dan Desain Penelitian}

Metode dalam penelitian ini menggunakan pendekatan kualitatif sebagai prosedur penelitian melalui proses penyelidikan berbasis pengamatan, penggambaran, pelukisan, dan pendeskripsian fakta-fakta dalam variabel-variabel subyek dan obyek fenomena sosial yang diteliti untuk menciptakan gambaran holistik, lengkap dan akurat disusun menjadi data deskriptif yang tampak sebagaimana adanya dalam sebuah latar ilmiah agar memecahkan masalah. Sementara, desain penelitian mengacu studi kasus dengan menggunakan pengamatan, pemeriksaan, pengumpulan informasi yang sistematis dan mendalam untuk memperoleh pemahaman terhadap kasus ketertarikan Indonesia untuk bergabung dalam perjanjian TPP agar diketahui parameter keuntungan atau kerugiannya di masa depan (Silalahi 2009, 30).

\subsection{Operasionalisasi Variabel}

Dari topik penelitian, tinjauan pustaka dan kerangka alur pemikiran maka dilakukan pendefinisian operasional variabelnya untuk menafsirkan petunjuk indikator-indikator kunci yang memberikan kepastian ruang lingkup dan batasan-batasan pembahasan topik penelitian dalam tiga variabel yaitu:

(1) Variabel ketertarikan Indonesia adalah pesan-pesan komunikasi dari aktor-aktor penting dan relevan dalam perpolitikan Indonesia menyiratkan kesan, minat, dan tingkah laku untuk bergabung dalam TPP. Ia diukur dari indikator ada atau tidaknya pernyataan-pernyataan yang dilontarkan oleh pejabat pemerintah Indonesia yang berisi pesan kuat membawa Indonesia bergabung dalam TPP.

(2) Variabel TPP adalah kesepakatan perdagangan bebas yang ditandatangani tanggal 4 Februari 2016 oleh MS (Australia, Brunei Darusalam, Kanada, Chile, Jepang, Malaysia, Meksiko, Selandia Baru, Peru, Singapura, dan Vietnam) — AS keluar tanggal 23 Januari 2017. Ia diukur dari indikator ada atau tidaknya fakta-fakta kronologis kejadian perjanjian MS; isi pesan perjanjian mencakup tujuan dan mekanisme pencapaian tujuan; dan karakteristik isi perjanjian yang mengandung prinsip-prinsip pengakuan hak-hak individu masyarakat MS untuk meraih kemakmuran sebesar-besarnya, struktur ekonomi kapitalistik, superioritas pasar, dan minimalisir peran negara dalam pasar.

(3) Variabel proyeksi Indonesia bergabung dalam TPP adalah gambaran yang memprediksi situasi dan kondisi Indonesia di masa depan ketika bergabung dalam TPP. Ia diukur dari empat indikator yang menentukan kategori Indonesia sebagai aktor negara dominan atau non-dominan dibandingkan MS TPP yaitu: (1) jumlah total populasi penduduk Indonesia yang ada berkombinasi dengan tinggi atau rendahnya tingkat kemiskinannya dibandingkan MS; (2) besaran GNI per-kapita atau rata-rata pendapatan per-kapita penduduk Indonesia sebagai tolok ukur kemakmuran dan pembangunan mereka dibandingkan MS (World Bank 2016); (3) skor HDI atau indeks pembangunan manusia dihitung dari harapan hidup, melek huruf, pendidikan, dan standar hidup sebagai tolok ukur kualitas masyarakat Indonesia dibandingkan MS (United Nations Development Program 2017); dan (4) skor GCA atau daya saing global dihitung dari faktor produksi nasional, kompetisi pasar domestik, kemampuan industri nasional bersaing dan berinovasi, dan peran pemerintah memfasilitasi kemajuan industri nasional sebagai tolak ukur keunggulan daya saing Indonesia di kancah global dibandingkan MS (Amadeo 2017). Apabila populasi penduduk Indonesia memiliki permasalahan kemiskinan yang rendah, besaran GNI per-kapita tinggi, skor HDI tinggi, skor GCA tinggi 
dibandingkan MS maka Indonesia berkategori dominan sehingga menguntungkan untuk bergabung dalam TPP. Sebaliknya permasalahan kemiskinan yang tinggi, besaran GNI per-kapita rendah, skor HDI rendah, skor GCA rendah dibandingkan MS maka Indonesia berkategori non-dominan sehingga merugikan ikut TPP karena hanya menjadi ‘wadah' eksploitasi dari MS dominan.

\subsection{Teknik Pengumpulan Data}

Penelitian ini teknik pengumpulan data dari sumber data "sekunder" berasal dari dokumentasi dalam penelaahan konten studi pustaka literatur buku, jurnal, artikel, dokumen, dan website laman resmi dan sahih beruang lingkup secara luas dan khusus tentang TPP dan Indonesia.

\subsection{Teknik Analisa Data}

Teknik analisa data penelitian dilakukan secara kualitatif melalui pengumpulan, penyeleksian, pemaparan, dan interpretasi mendalam berdasarkan tema, pokok permasalahan, kategori, dan fokus tertentu dalam masing-masing pola yang sudah ditentukan untuk dilakukan pengolahan, reduksi, dan penyajian data hingga penarikan kesimpulan komprehensif yang mendalam mengenai proyeksi Indonesia bergabung dalam TPP.

\subsection{Hipotesis}

Indonesia memiliki populasi penduduk besar yang dihadapkan permasalahan kemiskinan tinggi, GNI per-kapita rendah, HDI rendah, dan GCA rendah dibandingkan mayoritas MS TPP. Ia menjadi MS non-dominan ketika memutuskan bergabung dalam TPP untuk waktu yang dekat sehingga membuatnya menjadi sasaran eksploitasi dari MS dominan yang memanfaatkan fitur-fitur aturan main TPP.

\section{Hasil dan Pembahasan}

\subsection{Kesepakatan Trans-Pacific Partnership dan ketertarikan Indonesia dibawah kepemimpinan Presiden Joko Widodo}

Pada tahun 2002 dalam pertemuan Asia-Pacific Economic Cooperation (APEC) di Los Cabos, Meksiko, empat pemimpin negara "Pacific Rim" - Perdana Menteri Singapura, Goh Chok Tong, Perdana Menteri Selandia Baru, Helen Clark, Presiden Chile, Ricardo Lagos, dan Sultan Hassanal Bolkiah dari Brunei Darusalam membuka pembicaraan mengenai pentingnya perjanjian perdagangan bebas Trans-Pacific Strategic Economic Partnership Agreement (TPSEP). Clark menyebutnya sebagai, "keinginan bersama untuk menciptakan perjanjian perdagangan komprehensif dan berjangka panjang yang menetapkan tolak ukur berkualitas tinggi ... dalam wilayah APEC" (New Zealand Ministry of Foreign Affairs and Trade 2005, 5). Ia dilanjutkan enam perundingan draft yang disepakati di Wellington, Selandia Baru, tanggal 3 Juni 2005, berlaku efektif bulan Mei 2006 (Gao 2009, 81). Ini menambah keanggotaannya dari Australia, Kanada, Jepang, Malaysia, Meksiko, Peru, Vietnam, dan AS sambil menegosiasikan dan merumuskan draft TPP dalam negosiasi tertutup selama lima tahun yang tuntas bulan Oktober 2015.

Pada tanggal 4 Februari 2016, di Auckland, Selandia Baru, draft TPP ditandatangani pemimpin 12 negara - Australia, Brunei Darusalam, Kanada, Chile, Jepang, Malaysia, 
Meksiko, Selandia Baru, Peru, Singapura, Vietnam, dan AS. Jepang langsung meratifikasinya tanggal 20 Januari 2017, AS memutuskan keluar setelah presiden pengganti Barrack Obama, Donald Trump menandatangani "presidential memorandum" tanggal 23 Januari (Lee dan Itakura 2017, 10-12), dan usulan ratifikasinya dari Perdana Menteri Selandia Baru Jacinda Ardern disetujui Parlemen tanggal 11 Mei. TPP berisi 30 BAB fitur-fitur perdagangan bebas yang inklusif, akses pasar yang komprehensif, platform menuju pendekatan komitmen integrasi ekonomi regional, dan pengentasan tantangan perdagangan baru menyasarkan enam poin tujuan yaitu: (1) mendorong ekspansi perdagangan barang dan jasa di antara MS; (2) memfasilitasi dan menghilangkan hambatan perdagangan di antara mereka; (3) mendukung dan memajukan persaingan dagang yang adil dan bebas di antara mereka; (4) meningkatkan peluang investasi di antara mereka; (5) memberikan jaminan perlindungan yang memadai dan efektif atas HAKI di antara mereka; dan (6) menciptakan mekanisme efektif untuk mencegah dan penyelesaian sengketa perdagangan yang terjadi. Ini ditempuh melalui tujuh aspek pengaturan yakni: (1) pengurangan biaya hambatan tarif pajak hingga $0 \%$ dan non tarif secara bertahap 11.000 komoditas produk barang dan jasa MS; (2) pembukaan akses seluas-luasnya pengadaan barang dan jasa (tender) oleh pemerintah terhadap industri mereka; (3) pembebasan syarat bagi industri mereka melakukan investasi finansial, barang, dan/atau jasa tanpa beban penggunaan bahan baku yang melibatkan industri lokal; (4) penghilangan sikap diskriminatif pemerintah terhadap kepemilikan, subsidi, dan favoritisme BUMN untuk bersaing dengan industri antarMS; (5) jaminan perlindungan dan penegakkan hukum yang kuat dan seimbang oleh pemerintah mereka atas ekslusivitas HAKI dan tidak transfer teknologi; (6) Mahkamah arbitrase (Investor-State Dispute Settlement, ISDS) sebagai mekanisme hukum terpisah dari hukum nasional MS untuk penyelesaian sengketa antara investor dengan negara dan/atau warga negara secara damai; dan (7) penanganan bersama antarpemerintah MS terhadap isu-isu bisnis kontemporer dalam konservasi lingkungan hidup, sanitasi, fitosanitasi, internet, dan ekonomi digital (Fergusson, McMinimy, dan Williams 2016, 1-13).

Realisasi TPP dipercaya membuka akses pasar 792 juta jiwa penduduk dunia, setara $40 \%$ perekonomian dunia senilai \$28 triliun yang dianggap mampu meningkatkan pendapatan dunia sebesar \$104 milyar pertahun dipercaya membuka akses pasar 792 juta jiwa penduduk dunia, setara $40 \%$ perekonomian dunia senilai \$28 triliun yang dianggap mampu meningkatkan pendapatan dunia sebesar \$104 milyar pertahun (USNZ Council 2014). Ia mendorong ketertarikan Indonesia yang dipimpin Jokowi. Ini dituangkan dalam komunikasi politik yang disampaikan Jokowi ketika bertemu Obama di Washinton DC, AS, bulan Oktober 2015, dia berpidato menyatakan niat Indonesia bergabung dalam TPP dengan mengatakan "reformasi ekonomi membutuhkan waktu. Reformasi ekonomi adalah sebuah proses. Kita mungkin tidak sepenuhnya benar. Tetapi kita akan terus tampil dan membaik sampai kita bisa melakukannya dengan benar ... Kami adalah ekonomi terbesar di Asia Tenggara dengan populasi lebih dari 250 juta jiwa. Kami berniat bergabung dalam TPP" (The Guardian 2015). Bulan Februari 2016, Jokowi kembali menegaskan kepada media massa tentang keharusan Indonesia bergabung dalam TPP dengan mengatakan, "kalau enggak masuk blok-blok ... Pasti kalah bersaing ... Mau tidak mau kita harus masuk [TPP]. Karena ini era keterbukaan" (CNN Indonesia 2016). Menteri Sekretaris Kabinet, Pramono Anung turut mendukungnya, "Indonesia perlu ditantang, dipersiapkan tetapi juga kita tidak bisa menghindar [TPP] bahwa kita harus bisa adaptasi dengan perubahan pasar" (CNN Indonesia 2015). Begitu pula Pengamat ekonomi Universitas Indonesia, Faisal Basri yang menganggap pentingnya bergabung dalam TPP mengatakan "apabila Indonesia tak bergabung dengan TPP maka konsekuensinya adalah kalah bersaing dengan ... pesaing dagang Indonesia" (Kompas 2015).

Pernyataan Jokowi, Anung, dan Basri di atas menyampaikan pesan-pesan politik kuat yang berorientasi sinyal keinginan, minat, kesan, dan nilai untuk membawa Indonesia bergabung dalam TPP di masa depan. Kendati demikian, ada beberapa pihak menentangnya, seperti Wakil 
Ketua Dewan Perwakilan Rakyat (DPR) Indonesia, Agus Hermanto mengatakan, "kalau kita masuk TPP, kita betul-betul merugi ... dalam hal ini usaha kita lemah ... Dengan industri yang terbilang lemah, Indonesia hanya akan menjadi 'mangsa' pasar dari luar negeri (Media Indonesia 2015). Mantan Ketua Dewan Pertimbangan Presiden, Emil Salim turut menentang, dia percaya "TPP tidak hanya berpengaruh terhadap memburuknya ekonomi, tetapi juga tidak sesuai dengan nilai-nilai ideologi bangsa dan Nawacita" (Tempo 2016). Juga peneliti Pusat Studi Perdagangan Dunia Universitas Gadjah Mada, Riza Noer Arfani berpandangan skeptis dengan menyatakan "syarat-syarat dalam TPP terlalu sulit untuk Indonesia" (Podium 2016). Hingga saat ini, pemerintah Indonesia belum mengambil sikap tegas akan bergabung atau tidak dalam TPP karena masih dipelajari dan dikaji besaran untung atau ruginya oleh instansi-instansi yang berwenang.

\subsection{Proyeksi Indonesia dalam Trans-Pacific Partnership}

Perjanjian TPP yang berisi $30 \mathrm{BAB}$ terangkum dalam enam poin tujuan dan tujuh aspek pengaturan perdagangan bebas adalah bentuk pengakuan hak-hak individu kesetaraan, kebebasan, dan otonomi masyarakat MS untuk saling berkompetisi, bersaing, dan berinovasi meraih kekayaan, kemakmuran, dan kesejahteraan dalam struktur ekonomi kapitalis. Mereka sama-sama berhak memperebutkan, menguasai, dan mengontrol aset-aset produksi, industri, dan perdagangan 11.000 komoditas barang dan jasa strategis, mulai otomotif, elektronik, makanan, minuman, perkebunan, pertanian, properti, energi, transportasi, termasuk produk sensitif kesehatan, asuransi, keuangan, tender pemerintah, dan lain sebagainya tanpa hambatan tarif hingga $0 \%$ dan non tarif, tanpa beban penggunaan bahan baku industri lokal, tidak ada transfer teknologi, tidak ada keberpihakan pemerintah terhadap BUMN, memiliki ekslusivitas HAKI, dan dijamin hukumnya oleh ISDS. Ini menciptakan superioritas pasar di atas segalanya yang meminimalisir dan membatasi peran negara (pemerintah) sekecil mungkin. Pemerintah tidak mampu berbuat apapun, apalagi berpihak terhadap industri-industri nasional karena dihadapkan ISDS. Satu-satunya peran pemerintah hanya menangani masalah konservasi lingkungan hidup, sanitasi, fitosanitasi, internet, dan ekonomi digital (Carter dan Grim 2014).

Rancangan TPP di atas cenderung berbahaya bagi Indonesia apabila memutuskan bergabung dalam waktu dekat. Ia tidak terlibat perumusan draftnya menunjukan kepentingan nasional tidak diperhitungkan oleh MS, negosiasinya dilakukan tertutup mencerminkan adanya agenda-agenda 'terselubung' dari MS. Salim mencurigai "kesulitan membahas TPP bahwa negosiasi tentang dan hasilnya tidak transparan dan sifatnya tertutup ... TPP memperjuangkan ... kepentingan lobi bisnis yang kuat" (Tempo 2016). Paling krusial, Indonesia berpopulasi besar lebih dari 263 juta jiwa dan kaya sumber daya alam tanah, hutan, perkebunan, perikanan, minyak, gas, batu bara, dan lainnya berkategori non-dominan dibandingkan mayoritas MS lainnya. Kemiskinan tinggi sebesar 12,5\% 'menghantui' lebih dari 32 juta rakyatnya — jumlah terbesar dibandingkan MS lainnya kendati persentasenya lebih tinggi, Australia 13,30\% (3,2 juta jiwa), Singapura 26\% (1,4 juta jiwa), Jepang 15,7\% (20 juta jiwa), Selandia Baru $15 \%$ (708 ribu jiwa), Chile (2,5 juta jiwa), dan Peru 22,7\% (7,3 juta jiwa), terkecuali Meksiko 46,2\% (59 juta jiwa). GNI per-kapitanya sebesar $\$ 3.974$ terendah dibandingkan MS lain Australia $\$ 55.670$, Singapura $\$ 52.600$, Jepang $\$ 47.607$, Malaysia $\$ 11.028$, Peru $\$ 6.089$, dan seterusnya, kecuali Vietnam \$1.770. Kualitas SDM (HDI) memiliki skor 0,689 peringkat 113 dari 188 negara, terendah dibandingkan MS lain seperti Malaysia skor 0,789 peringkat 59, Brunei Darussalam skor 0,865 peringkat 30, Selandia Baru skor 0.915 peringkat 13, Meksiko 0,762 peringkat 77, kecuali Vietnam skor 0,683 peringkat 115. Kemampuan daya saingnya (GCA) skor 4,6 peringkat 34 dari 144 negara, setaraf Chile skor 4,6 peringkat 33, lebih baik dari Vietnam skor 4,2 peringkat 68, Peru skor 4,2 peringkat 65, Meksiko 4,3 peringkat 61, namun 
jauh tertinggal dari Australia, Singapura, Jepang, Malaysia, Kanada, Brunei Darussalam, dan

Selandia Baru (lihat Tabel 1).

Tabel 1. Perbandingan Populasi, Kemiskinan, GNI per-kapita, HDI, dan GCA Indonesia dengan anggota TPP tahun 2010- Juli 2017

\begin{tabular}{|c|c|c|c|c|c|c|}
\hline No & $\begin{array}{c}\text { Negara anggota } \\
\text { TPP \& } \\
\text { Indonesia }\end{array}$ & $\begin{array}{c}\text { Populasi } \\
\text { (Juli 2017) }\end{array}$ & $\begin{array}{c}\text { Kemiskinan } \\
2010-2015\end{array}$ & $\begin{array}{c}\text { GNI per- } \\
\text { kapita } \\
2016\end{array}$ & $\begin{array}{c}\text { HDI (rangking } \\
\text { dari 188 } \\
\text { negara) } \\
2014-2015\end{array}$ & $\begin{array}{c}\text { GCA } \\
\text { (rangking dari } \\
144 \text { negara) } \\
\text { 2016- Juli } \\
2017\end{array}$ \\
\hline 1 & Australia & 24.450 .561 & $13,3 \%$ & $\$ 55.670$ & $0,939(2)$ & $5,1(21)$ \\
\hline 2 & Singapura & 5.708 .844 & $26 \%$ & $\$ 52.600$ & $0,925(5)$ & $5,6(2)$ \\
\hline 3 & Jepang & 127.484 .450 & $15,7 \%$ & $\$ 47.607$ & $0,903(17)$ & $5,5(6)$ \\
\hline 4 & Malaysia & 31.624 .264 & $0,6 \%$ & $\$ 11.028$ & $0,789(59)$ & $5,2(20)$ \\
\hline 5 & Kanada & 36.624 .199 & $9,4 \%$ & $\$ 50.231$ & $0,920(10)$ & $5,2(15)$ \\
\hline 6 & Selandia Baru & 4.722 .913 & $15 \%$ & $\$ 36.842$ & $0.915(13)$ & $5,2(17)$ \\
\hline 7 & Brunei & 428.697 & $5 \%$ & $\$ 31.431$ & $0,865(30)$ & $4,8(28)$ \\
\hline 8 & Chile & 18.054 .726 & $14,4 \%$ & $\$ 15.019$ & $0,847(38)$ & $4,6(33)$ \\
\hline 9 & Meksiko & 129.163 .276 & $46,2 \%$ & $\$ 9.707$ & $0,762(77)$ & $4,3(61)$ \\
\hline 10 & Peru & 32.165 .485 & $22,7 \%$ & $\$ 6.089$ & $0,740(87)$ & $4,2(65)$ \\
\hline 11 & Vietnam & 95.540 .800 & $11,3 \%$ & $\$ 1.770$ & $0,683(115)$ & $4,2(68)$ \\
\hline $\mathbf{1 2}$ & Indonesia & $\mathbf{2 6 3 . 9 9 1 . 3 7 9}$ & $\mathbf{1 2 , 5}$ & $\mathbf{\$ 3 . 9 7 4}$ & $\mathbf{0 , 6 8 9 ( \mathbf { 1 1 3 } )}$ & $\mathbf{4 , 6 ( 3 4 )}$ \\
\hline
\end{tabular}

Sumber: Diolah dari (World Meters 2017; Trading Economics 2017; Index Mundi 2017; United Nations

Development Program 2016; World Economic Forum 2015; Central Intelligence Agency 2017; Australian Council of Social Service 2017; dan New Zealand Parliament 2011)

Kondisi di atas diperumit masalah birokrasi bisnis nasional yang berbelit-belit diwarnai 'tikus-tikus' korupsi yang terlalu rakus. Pakar Administrasi Publik Universitas Indonesia Vishnu Juwono mengatakan "beberapa survei indikator global menunjukkan bahwa birokrasi masih menjadi salah satu sumber inefisiensi dan penghambat usaha di Indonesia ... Inefisiensi birokrasi menempati urutan kedua di bawah korupsi sebagai faktor penghambat bisnis di negeri ini" (Kompas 2012 dan Juwono 2017), dan permasalahan pembangunan infrastruktur yang belum memadai. Asosiasi Pengusaha Indonesia (Apindo) Sofjan Wanandi melihat minimnya infrastruktur memicu daya saing Indonesia melemah, di samping birokrasi yang buruk. Dia mengatakan "bagaimana bisa bersaing kalau infrastruktur tidak ada dan birokrasinya lamban" (Muharti 2012 dan Indonesia Investments 2017). Ini membuat Indonesia hanya mampu bersaing ketat dengan Vietnam, namun sulit untuk bersaing dengan Peru, Chile atau Meksiko, apalagi harus bersaing melawan MS berstatus dominan seperti Australia, Singapura, Jepang, Malaysia, Kanada, Brunei Darussalam, dan Selandia Baru yang memiliki perusahaanperusahaan bersumber daya jaringan bisnis luas, modal finansial besar, pengetahuan tinggi, dan teknologi maju selayaknya Petronas (Malaysia), Temasek (Singapura), East Asia Mineral Corporation, (Kanada), Toyota (jepang), dan lain sebagainya hampir tidak mungkin dikalahkan. 
Sebagai contoh seluruh (total 138) perusahaan BUMN nasional berpendapatan $\$ 13,5$ miliar tahun 2014 tidak mampu melawan perusahaan Petronas berlaba bersih \$20 miliar di tahun yang sama, 20 di antaranya yang bergerak di sektor perbankan, perkebunan, properti, energi, transportasi, dan pengelolaan udara (Finansial Bisnis 2014), juga tidak bisa menandingi kinerja perusahaan Temasek Singapura dan Khazanah Malaysia, tidak ada perusahaan otomotif nasional yang dapat mengejar perusahan Jepang Toyota, Honda, Daihatsu, Suzuki, dan seterusnya (INSEAD 2017).

Tiga puluh BAB ketentuan-ketentuan TPP hanya memunculkan hubungan eksploratif MS dominan terhadap Indonesia yang melampaui batas-batas moral perdagangan produk barang, pengelolaan jasa, dan penyaluran investasi. Pengamat hubungan internasional Universitas Padjadjaran Teuku Rezasyah mengatakan "TPP berpotensi memperlemah pelaku usaha ... Mereka punya kemampuan teknologi, permodalan dan jaringan bisnis untuk menghancurkan kita" (Hidayat 2017). Mereka mampu mengambil alih pasar 11.000 sektor strategis nasional dengan menawarkan berbagai produk barang dan jasa unggul, berkualitas, berharga kompetitif, bahkan (mungkin) lebih murah, memenangkan pengadaan tender barang dan jasa pemerintah, dan mengabaikan Usaha Mikro Kecil dan Menengah (UMKM) daerah pelosok Kalimantan, Sulawesi, Maluku, dan Papua yang selama ini 30\% diuntungkan kebijakan "Hilirisasi Industri" (Indonesia for Global Justice 2016). Mereka turut mengancam untuk menggantikan eksistensi BUMN Indonesia yang memainkan peran sangat penting dalam kehidupan politik, ekonomi, dan sosial rakyat membuat 34 BUMN bermodal saham di atas 50\% pemerintah dan berpendapatan lebih \$200 juta seperti Pertamina, Telkom, PLN, Bank Mandiri, Bank BRI, dan lainnya berpotensi bangkrut (Yovanda 2015). Juga mematikan perusahaan nasional sektor informasi, pengetahuan, dan budidaya khas (teknologi, perkebunan, pertanian, perikanan, dan farmasi) seperti PT Metrodata Electronics, PT. K 24 Indonesia, PT. Kimia Farma dan lainnya karena tidak ada transfer teknologi dan ekslusivitas HAKI.

Pada akhirnya MS dominan berhasil membuat ekonomi Indonesia bergantung terhadap mereka. Perusahaan-perusahaan mereka memonopoli penuh ekonomi nasional sambil meraup untung bersama. Pemerintah tidak dapat lagi berbuat apapun karena dibungkam ancaman gugatan jutaan hingga miliaran dolar dalam Mahkamah Arbitrase ISDS yang kekuasaannya sulit diverifikasi, tidak terlegitimasi kedaulatan, tidak bertanggung jawab publik, dan tidak bisa dijadikan alat gugatan balik oleh negara atau warga negara apabila perusahaan mereka melanggar hukum nasional. Kegentingan, kebingungan, jeritan, dan tangisan rakyat yang tercekik menggelora akibat harga listrik, air, beras, gula, minyak, sekolah, rumah sakit, obatobatan generik selalu berubah-ubah semakin mahal mengikuti kehendak pasar (Ginanjar 2015). Ini sudah terlambat, satu-satunya 'hiburan' rakyat adalah tayangan 'sinetron' mengenai dialog antarpemerintah MS dan Indonesia mengenai konservasi lingkungan hidup, sanitasi, fitosanitasi, internet, dan ekonomi digital yang dari dulu hingga sekarang tidak jelas akar sampai ujung penyelesaian masalahnya (Podium 2016).

\subsection{Haruskah Indonesia bergabung dalam Trans-Pacific Partnership?}

Saat ini Indonesia memang belum memutuskan sikap bergabung atau tidak dalam TPP. Ia masih dipelajari dan dikaji oleh instansi berwenang dalam lintas Kementrian Koordinator Bidang Politik, Hukum, dan Keamanan, Kementerian Koordinator Bidang Perekonomian, Kementerian Perindustrian, Kementerian Luar Negeri, dan Kementerian Sosial. Namun, menyimak seluruh uraian di atas menunjukan bahwa status Indonesia berkategori non-dominan dibandingkan MS, terkhusus Australia, Singapura, Jepang, Malaysia, Kanada, Brunei Darussalam, dan Selandia Baru. Jumlah masyarakat miskin tertinggi dibandingkan mereka kecuali Meksiko, pendapatan (GNP) per-kapita jauh di bawah mereka kecuali Vietnam, kualitas (HDI) SDM tertinggal dari mereka kecuali Vietnam, dan daya saing nasional (GCA) lemah 
melawan mereka kecuali Meksiko, Peru, dan Vietnam, ditambah birokrasi bisnis berbelit-belit dan korup, serta pembangunan infrastruktur yang belum memadai. Selama persoalan-persoalan tersebut belum banyak kemajuan hingga tuntas, jangan pernah dipaksa (seolah-olah) siap bermain dalam TPP, karena jargon-jargonnya mengenai keterbukaan sistem ekonomi dunia, kompetisi, kemajuan, keuntungan bersama, dan 'omong kosong' lainnya berpotensi menjerat Indonesia dalam 'jurang' eksploitasi dari MS dominan melalui perusahaan besar, jaringan bisnis luas, modal finansial besar, pengetahuan tinggi, dan teknologi maju apabila bergabung.

Sudah cukup bagi kita (rakyat Indonesia) dijajah Belanda tiga setengah abad, 'diperkosa' Jepang tiga setengah tahun, 'digombali' IMF puluhan tahun, dan jangan tertipu lagi dengan TPP. Untuk itu, manfaatkan sebaik-baiknya yang sudah ada seperti ASEAN Community, AFTA, ASEAN, Australia and New Zealand FTA (AANZFTA), ACFTA, ASEAN-India FTA (AIFTA), ASEAN-Japan FTA (AJFTA), ASEAN-Korea FTA (AKFTA), Indonesia-Japan Economic Partnership (IJEP), dan seterusnya. Jadi komunikasi politik Jokowi, Anung, Basri, dan pendukungnya mengenai ikut serta dalam TPP, tidak perlu ditanggapi lagi, tidak penting diributkan kembali, apalagi dipusingkan, ambil sikap tegas menolak TPP untuk saat ini.

\section{Kesimpulan dan rekomendasi}

TPP adalah perjanjian perdagangan bebas paling ambisius, komprehensif, dan berstandar tinggi melampaui ketetapan standar World Trade Organization (WTO) beranggotakan MS Singapura, Selandia Baru, Chile, Brunei Darusalam, Australia, Kanada, Jepang, Malaysia, Meksiko, Peru, dan Vietnam - AS keluar Januari 2017. Ia berisi 30 BAB fitur-fitur perdagangan bebas dalam enam poin tujuan dan tujuh aspek pengaturan yang mengakui hak-hak individu masyarakat untuk saling berkompetisi, bersaing, dan berinovasi memperebutkan, menguasai, dan mengontrol aset-aset produksi, industri, dan perdagangan dalam superioritas pasar yang meminimalisir peran negara MS sekecil mungkin. Ini menarik minat Indonesia dibawah kepemimpinan Jokowi yang mengkomunikasikannya dalam pesanpesan politik kuat yang berorientasi sinyal keinginan, minat, kesan, dan nilai untuk membawa Indonesia bergabung dalam TPP. Kendati demikian, saat ini pemerintah Indonesia belum memutuskan sikap bergabung atau tidak karena masih dipelajari dan dikaji rasionalitasnya oleh instasi-instansi yang berwenang.

Penelitian ini membuktikan hipotesis bahwa posisi Indonesia yang berpopulasi besar dan kaya sumber daya alam berkategori non-dominan karena memiliki jumlah rakyat miskin terbesar dibandingkan MS kecuali Meksiko, GNI perkapita terendah kecuali Vietnam, HDI rendah kecuali Vietnam, dan daya saing nasional lemah kecuali melawan Meksiko, Peru, dan Vietnam, ditambah adanya masalah birokrasi bisnis berbelit-belit yang korup, dan pembangunan infrastruktur yang belum memadai. Apabila ia memutuskan bergabung TPP dalam waktu dekat proyeksinya hanya mampu bersaing ketat melawan Vietnam, sulit memenangkan persaingan melawan Peru, Chile, dan Meksiko, serta kalah bersaing melawan MS berkategori dominan yang memiliki perusahaan besar, jaringan bisnis luas, modal finansial besar, pengetahuan tinggi, dan teknologi maju seperti Australia, Singapura, Jepang, Malaysia, Kanada, Brunei Darussalam, dan Selandia Baru. Ini membuat mereka melakukan ketergantungan, monopoli, dan eksploitasi ekonomi dan sosial Indonesia dengan mengambil alih pasar 11.000 komoditas barang dan jasa, memenangkan pengadaan tender barang dan jasa pemerintah, pengabaian UMKM di daerah pelosok, menggantikan eksistensi BUMN, mematikan industri informasi, pengetahuan, dan budidaya khas, 'pembungkaman' pemerintah melalui ISDS, dan peralihan peran pemerintah yang disibukan mengurus masalah-masalah lingkungan hidup, sanitasi, fitosanitasi, internet, dan ekonomi digital daripada kebutuhan pokok masyarakatnya. 
Berdasarkan seluruh bahasan dan temuan artikel ini maka diberikan dua rekomendasi yang layak dipertimbangkan bagi akademisi, praktisi, dan pemerintah Indonesia untuk bergabung atau tidak dalam TPP, yaitu: (1) fase sekarang lebih tepat untuk menolak bergabung dalam TPP karena kalkulasi ketidakmampuan daya saing nasional melawan negara-negara dominan yang berdaya saing kuat seperti Australia, Singapura, Jepang, Malaysia, Kanada, Brunei Darussalam, dan Selandia Baru, oleh sebab itu, lebih baik memanfaatkan kerjasama yang ada semaksimal mungkin selayaknya ASEAN Community, AFTA, AANZFTA, ACFTA, AIFTA, AJFTA, AKFTA, IJEP, dan lain sebagainya; dan (2) kemungkinan keikutsertaan Indonesia dalam TPP di masa depan harus benar-benar melewati pertimbangan dan persiapan matang dengan memperhatikan keunggulan dan daya saing nasional yang mampu melawan MS dominan mengacu efektivitas, efisiensi, dan produktifitas populasi, kemiskinan rendah, GNI per-kapita tinggi, HDI tinggi, GCA tinggi, birokrasi bisnis anti-korupsi, dan infrastruktur memadai. 


\section{DAFTAR PUSTAKA}

\section{Buku}

Aggarwal, Vinod K., dan Seungjoo Lee. 2010. Trade Policy in the Asia-Pacific: The Role of Ideas, Interests, and Domestic Institutions. New York: Springer.

Arifin, Anwar. 2003. Komunikasi Politik: Paradigma, Teori, Aplikasi, Strategi dan Komunikasi Politik Indonesia. Jakarta: Balai Pustaka.

Burchill, Scott dan Adam Linklater. 1996. Theories of International Relations. Diterjemahkan oleh Sobirin, New York: ST Martin's Press.

New Zealand Ministry of Foreign Affairs and Trade. 2005. Trans-Pacific Strategic Economic Partnership Agreement National Interest Analysis. Auckland: NZMFAT.

New Zealand Ministry of Foreign Affairs. 2016. The Full Text of the Trans-Pacific Partnership Agreement (TPP). Auckland: NZMFA.

Silalahi, Uber. 2009. Metode Penelitian Sosial. Bandung: Refika Aditama.

\section{Jurnal}

Almond, A. Gabriel. 1956. "Comparative Political Systems.” The Journal of Politics 18: 409391.

Betzelt, Sigrid, Trevor Evans, Eckhard Hein, Hansjörg Herr, Martin Kronauer Birgit Mahnkopf, Achim Truger, dan Markus Wissen. 2014. "When one country's land gain is another country's land loss... The social, ecological and economic dimensions of sand extraction in the context of world-systems analysis exemplified by Singapore's sand imports." Institute for International Political Economy Berlin 36: 43-1.

Fergusson, Ian F., Mark A. McMinimy, dan Brock R. William. 2016. "The Trans-Pacific Partnership (TPP): In Brief." Congressional Research Service 7:13-1.

Gao, Shuchao Henry. 2009. "The Trans-Pacific Strategic Economic Partnership Agreement: High Standard or Missed Opportunity?.” Research Collection School Of Law 973:9579.

\section{Internet}

Amadeo, Kimberly. 2017. "What Is Competitive Advantage? Three Strategies That Work." The Balance, 31 Oktober, Diakses pada 12 November 2017. https://www.thebalance.com/what-is-competitive-advantage-3-strategies-that-work$\underline{3305828}$

Carter, Zach dan Ryan Grim. 2014. "Noam Chomsky: Obama Trade Deal A 'Neoliberal Assault' To Further Corporate 'Domination'.” Huffington Post, 13 Januari. Diakses pada 10 November2017. https://www.huffingtonpost.com/2014/01/13/noam-chomskyobama-trans-pacific-partnership n_ 4577495.html.

Ginanjar, Ging. 2015. "Plus minus niat gabung Kemitraan Trans-Pasifik TPP." $B B C, 28$ Oktober. Diakses pada 8 November 2017. http://www.bbc.com/indonesia/berita_indonesia/2015/10/151027_indonesia_tpp.

Hidayat, Faiq. 2017. "Jika gabung TPP, Pemerintah Jokowi buat kekeliruan besar." Merdeka, 27 Januari. Diakses pada 6 November 2017. https://www.merdeka.com/uang/jikagabung-tpp-pemerintah-jokowi-buat-kekeliruan-besar.html.

Julianto, Pramadia Arhando. 2016. "Ekonomi Indonesia Hanya Dikuasai oleh 20 Persen Penduduk Terkaya." Kompas, 6 Maret. . Diakses pada 12 November 2017. 
http://ekonomi.kompas.com/read/2016/04/06/155529426/Ekonomi.Indonesia.Hanya.Di kuasai.oleh.20.Persen.Penduduk.Terkaya.

Juwono, Vishnu. 2017. "Korupsi dan Macetnya Reformasi Birokrasi." Indonesia Corruption Watch (ICW), 31 Januari. Diakses pada 16 Agustus 2017.

http://antikorupsi.org/news/korupsi-dan-macetnya-reformasi-birokrasi.

Kasali, Reynald. 2016. "Perusahaan Induk Migas dan Ketahanan Energi". Kompas, 9

Desember. Diakses pada 12 November 2017.

https://www.pressreader.com/indonesia/kompas/20161209/281595240160056.

Lee, Hiro dan Ken Itakura. 2017. "U.S. Withdrawal from the Trans-Pacific Partnership and the Effects of Alternative Trade Integration Scenarios in the Asia-Pacific." University of Washington, Maret. Diakses pada7 Agustus 2017.

https://faculty.washington.edu/karyiu/confer/sea17/papers/Lee_Hiro.pdf.

Muharti, Anovianti. 2012. "Infrastruktur dan Birokrasi Jadi Hambatan Perdagangan." Neraca, 18 September. Diakses pada 16 November 2017.

http://www.neraca.co.id/article/19143/infrastruktur-dan-birokrasi-jadi-hambatanperdagangan.

Sumner Scott. 2016. "Neoliberalism: There is no alternative." Library Economics Liberty, 15 Juni. Diakses pada 4 Agustus 2017.

http://econlog.econlib.org/archives/2016/06/neoliberalism_t.html.

Yovanda, Yanuar Riezqi. 2015. "Indonesia Masuk TPP, BUMN Tak Berkutik." Sindo News, 6 November. Diakses pada 8 November 2017.

https://ekbis.sindonews.com/read/1059462/34/indonesia-masuk-tpp-bumn-tak-berkutik1446803974.

Australian Council of Social Service. 2017. "Poverty." Diakses 9 November. http://www.acoss.org.au/poverty/.

CIA. 2017. "World Factbook Population Below Poverty Line." Diakses 7 November. https://www.cia.gov/library/publications/the-world-factbook/fields/2046.html

CNN Indonesia. 2015. "Ingin Gabung TPP, Pemerintah Jamin Proteksi Industri Nasional" Diakses pada 2 Agustus 2017.

https://www.cnnindonesia.com/ekonomi/20151028181640-92-88004/ingin-gabung-tpppemerintah-jamin-proteksi-industri-nasional/.

CNN Indonesia. 2016. "Jokowi: Indonesia Segera Bergabung TPP." Diakses pada 2 Agustus 2017. https://www.cnnindonesia.com/ekonomi/20160222163558-78-112647/jokowiindonesia-segera-bergabung-tpp/

CNN Indonesia. 2016. "Jokowi: Indonesia Segera Bergabung TPP." Diakses pada 2 Agustus 2017. https://www.cnnindonesia.com/ekonomi/20160222163558-78-112647/jokowiindonesia-segera-bergabung-tpp/.

Detik. 2015. “Gubernur Papua Minta Jatah Lebih Besar dari Freeport.” Diakses pada 12 November 2017. http://finance.detik.com/energi/d-2825745/gubernur-papua-mintajatah-lebih-besar-dari-freeport.

Finansial Bisnis . 2014. "Ternyata, Profit 138 BUMN RI Kalah Besar Dibandingkan Petronas Malaysia.” Diakses pada 6 November 2017. http://finansial.bisnis.com/read/20140826/309/252753/ternyata-profit-138-bumn-rikalah-besar-dibandingkan-petronas-malaysia.

Index Mundi. 2017. "Countries.” Diakses 7 November. Diakses 7 November. https://www.indexmundi.com/factbook/countries.

Indonesia for Global Justice. 2016. "Lembar Fakta Ancaman Perjanjian TPP.” Diakses pada 6 November 2017. http://igj.or.id/wp-content/uploads/2016/05/Fact-Sheet-AncamanTerhadap-Buruh.pdf. 
Indonesia Investments. 2017. "Infrastruktur di Indonesia." Diakses pada 18 September 2017. https://www.indonesia-investments.com/id/bisnis/risiko/infrastruktur/item381.

INSEAD. 2017. "Global Talent Competitiveness Index Focuses on Talent and Technology." Diakses pada 6 November 2017. https://www.insead.edu/news/2017-global-talentcompetitiveness-index-davos.

Kompas. 2012. "Kadin: Rumitnya Birokrasi Penyebab Pengusaha dan Pejabat Negara Korup.” Diakses pada 11 Agustus 2017. http://nasional.kompas.com/read/2012/12/11/21452850/Kadin.Rumitnya.Birokrasi.Peny ebab.Pengusaha.dan.Pejabat.Negara.Korup.

Kompas. 2015. "Soal TPP, Faisal Basri Sebut Pola Pikir Pemerintah Terbolak balik." Diakses pada 4 Agustus 2017.

http://ekonomi.kompas.com/read/2015/11/14/135557226/Soal.TPP.Faisal.Basri.Sebut.P ola.Pikir.Pemerintah.Terbolakbalik.

Media Indonesia. 2015. "Gabung TPP, Agus: Indonesia Merugi." Diakses pada 4 Agustus 2017. http://mediaindonesia.com/news/read/20294/gabung-tpp-agus-indonesiamerugi/2015-11-03.

New Zealand Parliament. 2011. "Household Incomes, Inequality and Poverty." Diakses 9 November 2017. https://www.parliament.nz/en/pb/researchpapers/document/00PlibCIP181/household-incomes-inequality-and-poverty.

Podium. 2016. “TPP (Trans-Pacific Partnership): Haruskah Indonesia Ikut?.” Diakses pada 6 Agustus 2017. http://podium.id/trans-pacific-partnership/kerugian-gabung-tpp/

Tempo. 2016. “Terkuak Mengapa Jokowi Ingin Indonesia Gabung ke TPP.” Diakses pada 6 Agustus 2017. https://nasional.tempo.co/read/news/2016/01/30/078740769/terkuakmengapa-jokowi-ingin-indonesia-gabung-ke-tpp.

The Guardian. 2015. "Indonesia will join Trans-Pacific Partnership, Jokowi tells Obama." Diakses pada 2 Agustus 2017.

https://www.theguardian.com/world/2015/oct/27/indonesia-will-join-trans-pacificpartnership-jokowi-tells-obama.

Trading Economics. 2017. "GDP per capita.” Diakses 7 November. https://tradingeconomics.com/country-list/gdp-per-capita.

United Nations Development Programme (UNDP). 2016. "Human Development Index and its components ." Diakses 11 November 2017. http://hdr.undp.org/en/composite/HDI.

United Nations Development Programme (UNDP). 2017. "Human Development Index (HDI).” Diakses pada 4 Agustus. http://hdr.undp.org/en/content/human-developmentindex-hdi.

USNZ Council. 2014. “TPP and Trade.” Diakses pada 2 Agustus 2017. http://usnzcouncil.org/projects/tpp-and-trade/.

World Bank. 2016. “GNI per capita, Atlas method (current US\$).” Diakses pada 4 Agustus 2017. https://data.worldbank.org/indicator/NY.GNP.PCAP.CD?view=chart.

World Economic Forum. 2015. "Competitiveness Rankings.” Diakses 11 November 2017. http://reports.weforum.org/global-competitiveness-report-2014-2015/rankings/.

World Meters. 2017. "Countries in the world by population (2017)." Diakses 7 November. http://www.worldometers.info/world-population/population-by-country/. 